СУТНІСТЬ ПОНЯТТЯ «ПІДГОТОВКА МАЙБУТНЬОГО ВЧИТЕЛЯ УКРАЇНСЬКОЇ МОВИ І ЛІТЕРАТУРИ» В ІСТОРИКО-ПЕДАГОГІЧНОМУ ДОСЛІДЖЕННІ: ВАРІАТИВНІСТЬ ПІДХОДІВ

\title{
THE ESSENCE OF THE PREPARATION OF A FUTURE TEACHER OF THE UKRAINIAN LANGUAGE AND LITERATURE IN A HISTORICAL-PEDAGOGICAL RESEARCH: VARIETY
}

у статmі констатовано посилення уваги до процесу підготовки майбутніх учителів (зокрема, вчителів української мови і літератури) у вітчизняному науково-педагогічному дискурсі з огляду на перманентний процес ресрормування системи вітчизняної освіти. Стверджено, що сучасні зміни мають враховувати історичний досвід педагогічної галузі у підготовиі вчителів та сучасні підходи до визначення тих чи тих понять педагогічного тезаурусу. Тому визначення специфріки підготовки майбутнього вчителя української мови та літератури у певних хронологічних межах передбачає необхідність встановлення сучасного погляду на базові поняття та їх уточнення відповідно до сочіокультурних умов певного історичного проміжку. Звернення до науково-педагогічних джерел щодо поняття «профресійна підготовка майбутніх учителів» демонструє багатоаспектність пропонованих сучасною наукою дефініцій, що дало підстави для ствердження про наявність у сучасному науково-педагогічному дискурсі декількох умовних підходів до визначеного поняття: змістового, процесуального, комплексного тощо. Змістовий аспект розгляду питання акцентує увагу на фраховій підготовці майбутнього вчителя, процесуальний - на спрямуванні навчальних дій; комплексний - на сукупності змістових та процесуальних компонентів.

Теоретичний аналіз науково-педагогічних праць, присвячених питанню професійної підготовки вчителів, дав змогу дійти висновку, що переважно змістовий підхід демонструють наукові дослідження з історії педагогіки, коли торкаються проблем професійної підготовки вчителів, зокрема вчителів української мови і літератури. Акцентовано на особливості сучасного визначення поняття «вчитель української мови і літератури», яке поступово замінюється поняттям «вчитель-срілолог», що передбачає посилення уваги до фрахової та психолого-педагогічної (практичноі) підготовки, які забезпечують виконання професійних завдань на відповідному теоретичному та практичному рівнях. Зроблено висновок, що історико-педагогічне дослідження варто проводити з опорою на комплексний підхід, що має врахувати особливості розвитку системи освіти на різних етапах суспільного розвитку. Застосування комплексного підходу дає змогу зважити на об'єктивні передумови, врахувати зовнішні та внутрішні чинники, що спрямовували підготовку вчителя української мови і літератури на тлі розвитку вітчизняної системи педагогічної освіти.

Ключові слова: майбутній учитель, учитель української мови і літератури, історичний досвід, історико-педагогічне дослідження, комплексний підхід.
In the article, strengthening of attention is established to the process of preparation of future teachers (in particular teachers of Ukrainian and literature) in home scientifically-pedagogical discours, taking into account the permanent process of reformation of the system of home education. It is ratified that modern changes must take into account historical experience of pedagogical industry in preparations of teachers and modern going near determination those or those pedagogical concepts to the thesaurus. Therefore determination of specific of preparation of future teacher of Ukrainian and literature in certain chronologic limits envisages the necessity of establishment of modern look to the base concepts and their clarification in accordance with the sociocultural terms of certain historical interval.

An address to the scientifically-pedagogical sources in relation to a concept "professional preparation of future teachers" demonstrates multidimensionalness of offered modern science of definitions, that grounded in order to ratify about a presence in modern scientifically-pedagogical discours of a few conditional going near the defined notion: semantic, judicial, complex and others like that. The semantic aspect of consideration of question accents attention on professional preparation of future teacher, judicial on aspiration educational actions; complex - on totality of semantic and judicial components.

The theoretical analysis of the scientificallypedagogical labours sanctified to the question of professional preparation of teachers allowed to come to the conclusion, that mainly rich in content approach is demonstrated by scientific researches from history of pedagogics, when touch problems of professional preparation of teachers, in particular teachers of Ukrainian and literature. It is accented on the feature of modern determination of concept "teacher of Ukrainian and literature", that is gradually replaced by a concept "teacher-philologist", that envisages strengthening of attention to professional and psychology-pedagogical (practical) preparation, that provide implementation of professional tasks on corresponding theoretical and practical levels. Drawn conclusion, that history-pedagogical research it costs to conduct with support on complex approach that must take into account the features of development of the system of education on the different stages of community development. Application of complex approach allows to weigh on objective preconditions, take into account external and internal factors that directed preparation of teacher of Ukrainian and literature on a background development of the home system of pedagogical education. Key words: future teacher, teacher of Ukrainian and literature, historical experience, history-pedagogical research, complex approach.
Криворізького державного педагогічного університету 
Постановка проблеми у загальному вигляді. У сучасних умовах розвитку вітчизняної освіти питання підготовки вчителя, зокрема вчителя української мови та літератури, постає надзвичайно гостро. Повністю поділяючи думку О. Біляковської про те, що «проблема якісної профресійної підготовки майбутніх учителів є важливим складником модернізації української освіти, навколо якого мають здійснюватися інноваційні освітні процеси у сучасному європейському просторі» [5, с. 126], вважаємо за необхідне підкреслити доцільність використання історико-педагогічного досвіду в модернізаційних процесах.

Аналіз останніх досліджень і публікацій. Зазначимо, що питання підготовки майбутніх учителів (зокрема, вчителів української мови і літератури) масштабно представлене у психолого-педагогічному дискурсі.

Історико-педагогічні, методичні та фрілологічні аспекти підготовки вчителів української мови і літератури, особливості мовної політики в Україні в минулому та сучасності відобразили в своїх працях В. Бабенко, Л. Базиль, Н. Баранник, І. Варнавська, І. Гайдай, І. Гамрецький, Т. Гнаткович, О. Демська та Е. Мальцев, С. Караман, О. Куцевол, Л. Мірошниченко, Є. Пасічник, М. Пентилюк, О. Семиног та ін. Важливо констатувати, що кількість наукових публікацій стосовно розглядуваного питання 3 кожним роком зростає, що пояснюється його актуальністю для вітчизняної системи освіти, зважаючи на посилення вимог до особистості сучасного вчителя, його фраховості та уваги до української мови як державної, мови навчання у вітчизняних закладах освіти.

Виділення не вирішених раніше частин загальної проблеми. Аналітичне вивчення наукових праць вітчизняних учених дає підстави до узагальнення щодо невичерпності проблеми підготовки майбутнього вчителя української мови та літератури в історико-педагогічному контексті та необхідності конкретизації базових понять проблеми з огляду на сучасний розвиток педагогічних досліджень.

Мета статті - окреслення провідних підходів до визначення поняття «профресійно-педагогічна підготовка майбутнього вчителя української мови та літератури» з урахуванням специфріки історикопедагогічних досліджень.

Виклад основного матеріалу. Вивчення процесу розвитку вітчизняної системи педагогічної освіти в історико-педагогічному дослідженні актуалізує питання конкретизації його поняттєвого апарату в двох аспектах: з позицій сучасного розвитку педагогічної науки та з позицій конкретно історичного періоду/етапу розвитку педагогічного явища (феномена, процесу). Принцип історикочасової корекції передбачає врахування можливої специфріки у тлумаченні педагогічних понять, що стають базовими для дослідження. Це загалом створює можливість повноцінного та всебічного висвітлення явища, яке аналізується (принцип голографрічності, за А. Бєлкіним та $€$. Ткаченко). Отже, у своєму дослідженні специфіки підготовки майбутнього вчителя української мови та літератури у визначених хронологічних межах ми передбачили необхідність встановлення сучасного погляду на конкретне поняття та можливості його уточнення відповідно до соціокультурних умов певного історичного проміжку.

Насамперед наголосимо, що у педагогічному дискурсі професійна підготовка вчителя розглядається як невід'ємний складник системи вищої педагогічної освіти [3, с. 85]. Проведене Г. Лещенко осмислення фрілософської, психологічної й педагогічної літератури дало підстави стверджувати, що «професійну підготовку витлумачують як цілеспрямований процес опанування реальними та потенційними працівниками (студентами, курсантами, слухачами) профресійних знань і вмінь для набуття навичок, необхідних під час виконання певних видів робіт» [9, с. 422]. Більш широко 3 позицій системного підходу розуміє професійну підготовку І. Манохіна, коли наголошує, що «професійна підготовка $€$ складною багаторівневою педагогічною системою, що включає певну сукупність цілей, змісту, фрорм, методів, засобів та технологій, зумовлених сутнісними потребами суб'єктів педагогічної взаємодії. Крім того, це процес і результат фрормування готовності особистості до виконання певної професійної діяльності» [10, с. 131]. Отже, у наведених вище визначеннях поняття «професійна підготовка» визначальними словами стають «процес» та «система», що дає змогу припустити умовну наявність процесуального та комплексного (оскільки наведене вище визначення системи відбувається через поняття «сукупність», а отже, комплекс).

Проте звернення до науково-педагогічних джерел щодо поняття «професійна підготовка майбутніх учителів» демонструє багатоаспектність пропонованих сучасною наукою дефініцій. Як «інтегративну систему, яка поєднує відносно самостійні, але взаємозалежні і взаємозумовлені системи підготовки: спеціально-наукову, психолого-педагогічну, загальнокультурну, кожна з них виконує специфічні завдання», розглядає профресійну підготовку педагога у закладах вищої освіти М. Васильєва [6, с. 17]. У цьому визначенні привертає увагу той фракт, що воно ґрунтується на переліку систем, що визначають зміст освіти. Схожий підхід демонструє Л. Йовенко, коли вказує, що система професійної підготовки майбутніх учителів містить такі складники, як: загальноосвітній, профресійний та спеціальний [8, с. 56].

Сукупність позицій сучасних учених дає змогу стверджувати про наявність декількох умовних підходів: змістового, процесуального, комплек- 
сного тощо.

Зокрема, на змістовому аспекті наголошує О. Абдулліна, коли стверджує, що вказана «система професійної підготовки майбутніх учителів» складається 3 декількох підсистем (суспільнополітичної, спеціально-наукової, психолого-педагогічної й загальнокультурної) [1]

Процесуальний підхід, на нашу думку, є головним у визначенні, яке подає В. Берека. Розглядаючи систему фрахової підготовки менеджерів освіти, вчений включає до їі складу «сукупність засобів, методів і процесів, необхідних для створення організованого, цілеспрямованого педагогічного впливу на формування особистості із заданими якостями» [4, с. 6], тож до системоутворюючих елементів учений відносить «загальнолюдські цінності, суть, мету, завдання та особливості управлінської діяльності, закономірності і принципи фрахової підготовки» [4, с. 6]. Такий підхід частково підтримує М. Васильєва, коли констатує, що підготовка - це «процес фрормування, удосконалення знань, умінь, навичок, якостей особистості, необхідних для виконання визначеної діяльності, здійснюваної в ході навчання, самоосвіти або професійної діяльності» [7].

Елементи комплексного підходу демонструє І. Манохіна, яка конкретизує процес профресійного становлення фрахівця відповідно до «змісту циклів навчальної підготовки», в якому виокремлює такі складники, як: психолого-педагогічна підготовка («система знань про фрактори, що сприяють особистісному зростанню; саморозвиток та самовиховання; організація навчального процесу в різних соціокультурних умовах; володіння уміннями психолого-педагогічної діагностики, аналізу та проєктування соціально-педагогічної роботи; проєктування, реалізація, оцінка і корекція навчального процесу»), предметна підготовка («володіння уміннями аналізу та проєктування соціальнопедагогічної діяльності; виявлення потреб дітей, створення умов для їхнього гармонійного розвитку; уміння застосовувати методи соціологічних та соціально-психологічних досліджень у професійній діяльності) та загальнокультурна підготовка(«використаннянакопиченогодосвідудлярозвитку творчих здібностей особистості») [10, с. 131]

Теоретичний аналіз науково-педагогічних праць, присвячених питанню профресійної підготовки вчителів, дає нам змогу зробити проміжний висновок, що переважно змістовий підхід демонструють наукові дослідження з історії педагогіки, коли торкаються проблем професійної підготовки вчителів, зокрема вчителів української мови і літератури.

Зокрема, О. Семеног у цій підготовці виокремлює декілька підсистем: ідейно-теоретичну, лінгвістичну, літературознавчу, психолого-педагогічну та методичну [11, с. 36]. Очевидно, що науковець сконцентрувала свою увагу на змістовому компоненті профресійної підготовки вчителів, проте значне місце в цьому процесі належить педагогічній практиці, яка забезпечує практичну готовність майбутнього вчителя до педагогічної діяльності, оскільки «сприяє активному фрормуванню професійної спрямованості мислення і діяльності майбутніх учителів, розвитку поваги й любові до педагогічної професії і до дітей» [12, с. 279]. Це дає нам змогу стверджувати про наявність тут частки процесуального підходу.

Тому важливим, на нашу думку, буде уточнення, зроблене Л. Базиль, яка підкреслює «своєрідність професійної підготовки майбутніх учителів-словесників, що передбачає синтетичне врахування закономірностей педагогічної й фрілологічної освіти» [2, с. 49]. Педагогічну освіту забезпечують теоретичні дисципліни психолого-педагогічного циклу та педагогічна практика.

Відповідно до логіки наукового пошуку вважаємо за доцільне звернутися до матеріалів докторської дисертації Л. Базиль, яка аналізує дефрініції поняття «вчитель української мови та літератури». 3-поміж іншого вчена вказує, що професія «вчитель української мови та літератури» отримала офріційне затвердження лише у 1918 р., проте у чинному класифрікаторі професій (Державний класифрікатор професій ДК 003:2010) таку професію не виокремлюють. Тут, за спостереженням Л. Базиль, «визначено професії: вчитель середніх навчально-виховних закладів (код КП - 2320; код ЗКППТР - 25157); профресіонали в галузі фрілології, фрілолог, фрілолог-дослідник (код КП - 2444; код ЗКППТР - 2444.1, 2444.2); профресіонали в галузі літератури (код КП - 2451); літературознавці (код КП - 2451; код ЗКППТР - 2451.1)» [2, с. 46]. Співставлення професійних фрункцій перелічених фрахівців дає змогу дослідниці стверджувати про спільність професій «філолог» та «вчитель-фрілолог», які у XX ст. диференціювали, наголошуючи, що «фрілолог - це фрахівець, який займається наукою, а вчитель літератури - це фахівець, який опанував основи літературознавства, теоретично і практично підготовлений до виконання завдань шкільної літературної освіти, щоб викликати стійкий усвідомлений інтерес до читання художніх творів, розуміння ролі літератури в житті кожної людини» [2, с. 46]. Очевидно, що за таких умов на перше місце у підготовці вчителя української мови і літератури мають висуватися фрахові (фрілологічні) дисципліни, дисципліни психолого-педагогічні (як і педагогічна практика) набувають прикладного характеру.

Утім, нині відбувається наближення у фрункціональних обов'язках визначених фрахівців, що демонструє поступове ствердження замість традиційної «предметної» вказівки словосполучення «вчитель-фрілолог», яке спостерігаємо у низці сучасних дисертаційних досліджень (О. Дуплій- 
чук «Профресійно-педагогічна підготовка майбутніх учителів-орілологів до застосування проєктно-комунікативних технологій», О. Циганок «Підготовка майбутнього вчителя-орілолога до українознавчої роботи в школі», О. Чайка «Підготовка майбутніх учителів-фрілологів до організації позакласної творчої діяльності учнів загальноосвітніх закладів», С. Процька «Комп'ютерно орієнтована методика орормування профресійно-педагогічної компетентності майбутніх учителів-орілологів»).

Звернення до тексту зазначених вище наукових праць переконує, що їхні автори уникають конкретизації самого поняття «вчитель-фрілолог», проте експериментальна частина роботи доводить розширене розуміння фрахової спеціалізації. Тобто переважно йдеться про «студентів галузей знань: 01 «Освіта/Педагогіка» (спеціальність 014 Середня освіта), 03 «Гуманітарні науки» (спеціальність 035 Філологія) [13, с. 122] чи «майбутніх учителів, що навчаються за напрямом підготовки 6.020303 «Філологія. Українська мова і література. Додаткова спеціальність - Мова і література (англійська)» [14, с. 29]. Тому у своїй роботі ми спиралися на міркування Л. Базиль, яка представляє таке визначення: «вчитель української мови і літератури - це фрахівець, який засобами художніх, публіцистичних, наукових, літературнокритичних текстів виховує учнів як активних громадян України, творчих читачів, здійснює шкільну мовно-літературну підготовку, орієнтуючись на вітчизняні і світові досягнення з педагогічних, психологічних і фрілологічних наук, і самоутверджується, розвиваючи індивідуальний стиль професійної діяльності» [2, с. 47].

Отже, професійна підготовка майбутнього вчителя української мови і літератури передбачає фрахову та психолого-педагогічну (практичну) підготовку, які забезпечують фрахівцю виконання професійних завдань на відповідному теоретичному та практичному рівнях.

3 огляду на зазначене вище вважаємо, що в історико-педагогічному дослідженні використання комплексного підходу до пояснення визначеного поняття вважаємо ключовим. Оскільки такий підхід дає можливість зважити на об'єктивні чинники та передумови, які визначали у різні часові проміжки сутність підготовки майбутнього вчителя (зокрема, вчителя української мови і літератури) для професійної (педагогічної) діяльності. Тож повністю поділяємо думку М. Васильєвої, яка стверджує, що «зміст профресійної підготовки педагога визначається потребами соціального розвитку суспільства, зі зростанням вимог до представника педагогічної професії, характеру його діяльності в системі професійної підготовки відбувається постійний процес творчого пошуку шляхів і технологій перебудови її на основі сучасних педагогічних можливостей» [7, с. 39]. Також додамо, що звернення до історико-педагогічних джерел дає змогу простежити зміни у співвіднесенні теоретичного та практичного складників у навчальних планах із підготовки вчителів української мови і літератури у різні часові проміжки.

Висновки. Узагальнюючи, можемо констатувати переважну увагу науковців до змістового та процесуального пояснення поняття. Проте історико-педагогічне дослідження варто проводити 3 опорою на комплексний підхід, що має врахувати особливості розвитку системи освіти на різних етапах суспільного розвитку. Отже, вважаємо, що застосування комплексного підходу дає змогу врахувати зовнішні та внутрішні чинники, що спрямовували підготовку вчителя української мови і літератури на тлі розвитку вітчизняної системи педагогічної освіти.

\section{БІБЛІОГРАФІЧНИЙ СПИСОК:}

1. Абдуллина О.А. Общепедагогическая подготовка учителя в системе высшего педагогического образования. Москва : Просвещение, 1990. 141 с.

2. Базиль Л.О. Теоретичні і методичні засади розвитку літературознавчої компетентності майбутніх учителів української мови і літератури : дис. ... д-ра пед. наук : 13.00.04. Київ, 2016. 571 с.

3. Безлюдна В.В. Теорія і практика професійної підготовки майбутніх учителів іноземних мов у вищих педагогічних навчальних закладах України (1948-2016 рр.) : автореф. дис. ... д-ра пед. наук : 13.00.01; 13.00.04. Рівне, 2018. 51 c.

4. Берека В.Є. Теоретико-методичні основи фрахової підготовки магістрів 3 менеджменту освіти : автореф. дис. ... д-ра пед. наук : 13.00.04. Київ, 2008. 42 с.

5. Біляковська О.О. Професійна підготовка майбутніх учителів природничо-математичних дисциплін: якісний вимір. Збірник наукових праць Херсонського державного університету. Педагогічні науки. 2017. Випуск LXXX. Том. 2. С. 125-129.

6. Васильєва М.П. Деонтологічний компонент підготовки сучасного педагога в умовах вищого навчального закладу. Вісник Дніпропетровського університету імені Альфреда Нобеля. Серія «Педагогіка $i$ психологія». 2011. №2 (2). С. 14-20.

7. Васильєва М. Роль деонтологічної підготовки у процесі професійної підготовки сучасного педагога. Проблеми інженерно-педагогічної освіти. 2010. № 26-27. С. 36-41.

8. Йовенко Л.І. Підготовка студентів-орілологів вищого педагогічного навчального закладу до родинного виховання : дис. ... канд. пед. наук : 13.00.04. Умань, 2005. $274 \mathrm{c}$.

9. Лещенко Г.А. До питання професійної підготовки майбутніх фрахівців. Young Scientist. 2017. № 3 (43). C. 421-426.

10. Манохіна І.В. Проблема професійної підготовки срахівців соціально-педагогічної ссрери в науковій літературі. Вісник Дніпропетровського університету імені Альфреда Нобеля. Серія «Педагогіка і психологія». Педагогічні науки. 2015. №1 (9). C. $128-134$. 
11. Семеног О.М. Тенденції професійної підготовки майбутніх учителів української мови і літератури (70-ті роки XX століття). Рідна школа. 2004. № 12. С. 36-38.

12. Пархета Л. Формування фрахової компетентності студентів-фрілологів у процесі педагогічних практик. Збірник наукових праць Уманського державного педагогічного університету. 2014. Ч. 2. С. 277-282.
13. Процька С.М. Комп'ютерно орієнтована методика формування професійно-педагогічної компетентності майбутніх учителів-срілологів : дис. ... канд. пед. наук : 13.00.04. Київ, 2019. 304 с.

14.Чайка О.В. Підготовка майбутніх учителівфрілологів до організації позакласної творчої діяльності учнів загальноосвітніх закладів : дис. ... канд. пед. наук : 13.00.04. Одеса, 2018. 333 с. 